\title{
The Effects of Monitoring and Evaluation Systems on Organizational Performance: A Case of Tanzania Airport Authority-Dar es Salaam, Tanzania
}

\author{
Godfrey Joseph Masawe and Juliana Isanzu
}

\begin{abstract}
Worldwide public sector and private sector put more effort in promotion of good environment for conducting monitoring and evaluation to the project conducted within their organization for the purpose of increase transparency, strengthen accountability, and improve organization performance. The study aims to determine the role of Monitoring and Evaluation systems on the Organizational performance and to examine resource monitoring and evaluation affect organization performance. A case of Tanzania Airport Authority. The study deployed descriptive quantitative research design, the study used Slovenes formula to obtain sample size of 187 from targeted population was 350 employees of TAA located in Ilala Municipality and purposively sampling was used. Questionnaire, and documents reviewed were used as the research instruments for collecting data needed in this study. The study uses multiple regression analysis models to test the relationship between monitoring and evaluation systems on organizational performances. The study concluded that monitoring and Evaluation systems improves organization performance in Tanzania and recommended that any organization(both private and public) should employ constant improvement in monitoring and Evaluation system in order to reach organization For the very rationale monthly time set of data has been approved from Jan 2014 to Dec 2019. The investigative outline contains.
\end{abstract}

Index Terms - monitoring and Evaluation systems and Organizational performance.

\section{INTRODUCTION}

Monitoring is ongoing series by which stakeholders obtain regular feedback on the progress being made towards achieving their goals and objectives while evaluations was independent assessment of either completed or ongoing activities to determine the extent to which they are achieving desired objectives and contributing to decision making within the organization [1].

Monitoring focuses on the implementation process and asks the key question of how well is the program being implemented evaluation analyses the implementation process, Evaluation measures how well program activities have met objectives, examines extent to which outcomes can be attributed to project objectives and describes quality and effectiveness of program by documenting impact on

\footnotetext{
Published on October 30, 2020.

Godfrey Joseph Masawe, Kampala International University, Tanzania.

(e-mail: masawegodfrey71@gmail.com)

Juliana Isanzu, Kampala International University, Tanzania.

(e-mail: julianaisanzu ${ }^{\circledR}$ gmail.com)
}

participants and community. Monitoring generates periodic reports throughout the program cycle, focuses on project outputs for monitoring progress and making appropriate corrections, highlights areas for improvement for staff and tracks financial costs against budget [1].

Evaluation is used in government sector to increase transparency, strengthen accountability, and improve performance, whereas performance management systems establish outcome oriented goals and performance targets, monitor progress, stimulate performance improvements, and communicate results to higher policy levels and the public [2].

A monitoring \& Evaluation system in Africa emerged largely from observations of the practice of $M \& E$ in countries outside Africa and was, therefore, a relatively late entrant to Africa. The entry of M\&E system into Africa has been largely through donor programmes and accompanied by an import of theories and methodologies that are largely northern in origin [3]. On the other hand, M\&E systems in Africa have taken on a transformative and social justice emphasis. M\&E demonstrates societal transformation which comes about when there is a greater transparency and accountability of its operations for the purpose of supporting the deepening of democracy [4].

Tanzania, like any other countries in the world has been grappling with how to ensure efficiency and effectiveness in service delivery and enhanced governance. There is evidence of a growing number of countries perusing the path of results orientation by building or strengthening their government monitoring and evaluation systems [5]. While monitoring has been described as the systematic and routine collection of information's from projects and programmes [6].

Tanzania adopted M\&E framework known as the Monitoring and Evaluation Policy of 2014. This Policy was to guide government departments, organization to adopt Monitoring and Evaluation systems as formulated in the Monitoring \& Evaluation Policy of 2014.

According to the Monitoring and Evaluation Policy of Tanzania of 2014, the policy states the purposes of the policy is to understand what encompasses M\&E Systems and use the understanding to improve the management of public sector. Understand the essential indicators for systematically building a Monitoring and Evaluation Systems; Design, build and sustain their institutional Monitoring and Evaluation Systems, identify problems existing in M\&E Systems and develop capacity building programmes for improvement; and take measures to strengthen Monitoring and Evaluation Systems on the organization performance [7]. 


\section{A. Statement of The Problem}

Monitoring and Evaluation systems improve efficiency and sustainability of project management [8]. Tanzania revealed Policy that helps effective Monitoring and Evaluation systems to help management of projects undertaken by government departments.

There are problems arising in the different projects undertaken by the government in Tanzania, for example DOWASCO, TANESCO, THA, JNIA, NHC, UDA and others. All these projects have shown different problems such as mismanagement of project, failure in timely completion of projects, decreasing in revenue and poor services delivered by employees whom are employed in the projects, this rise the question "what are effects of monitoring and evaluation systems on organizational performance: a case of Tanzania airport authority Dar es salaam, Tanzania?

Majority of government project organization are still weak whereas devotion given to monitoring and evaluation systems is not steady throughout the organization and it was observed that evaluation in government project should be developed in order to bring about effective managements of monitoring and evaluation systems, whereas there had been a resolution for project mismanagement, little remittance of revenue and timely completion of project. All these bring a room for a study to be conducted so as to understand the effects of monitoring and evaluation systems on the organizational performance.

Görgens and Kusek [9] in United States of America conducted a study concerning with Making monitoring and evaluation systems work. In their study they revealed that Monitoring and Evaluation is a powerful public management tool that can be used to improve the way governments and organizations achieve results.

\section{OBJective Of THE StUdy}

\section{A. General Objective}

The general objective of this study was to assess effects of Monitoring and Evaluation systems on the organization performance of the Tanzania Airports Authority.

\section{B. Specific Objectives}

Specific objectives of the study:

i. To determine the role of Monitoring and Evaluation systems on the Organizational performance.

ii. To examine resource monitoring and evaluation affect organization performance.

iii. To determine the relationship between Monitoring and Evaluation systems and organization performance of the Tanzania Airports Authority.

\section{LITERATURE REVIEW}

A. The Effects of Monitoring and Evaluation Systems on Organizational Performance

Görgens and Kusek [9] conducted a study concerning with Making monitoring and evaluation systems working on the United States of America (USA). In their study they revealed that Monitoring and Evaluation was a powerful public management tool that can be used to improve the way governments and organizations achieve results and sustaining an M\&E system that can produce trustworthy, timely, and relevant information on the performance of government, civil society, or private sector projects, programs, and policies requires that one overcome many $\mathrm{M} \& \mathrm{E}$ system challenges and approach the implementation of such a system with experience, skill, and real institutional capacity systems.

Naidoo [3] in conducted a study concerning with the role of monitoring and evaluation in promoting good governance in South Africa. In his study he revealed that monitoring and evaluation within the organization helps to provide good governance by increasing transparency and helped to deepen democracy as it has produced the information for engagement on performance of the State. It has been limited in taking on board citizens to date, and where it has assessed service delivery, the changes have been limited.

Tukwayo [10] examined level of and role of M\&E systems in the government in the provision of sustainable public housing development in Malawi. The study highlighted the existence of poor $M \& E$ practice in public organizations and recommended the establishment of dynamic vibrant institutions which would ensure the presence of participatory principle, consensus orientation, strategic vision, effectiveness and efficiency, transparency and the rule of law in all administrative and political institutions. However, this study focused on provision of sustainable public housing while the proposed study was focused on Organization project. However, these studies ware done in the foreign country with different administrative dynamics.

Govender [11] conducted a study concerning with Monitoring and evaluation systems for enhancing governance and government in South Africa. In their study he revealed that monitoring and evaluation within the organization reduce factors such as costs of employee turnover and increase employee productivity, employee morale, employment equity legislation, criticality and scarcity of skills, and availability of development and employment opportunities

Raimondo [12] conducted a study concerning with what difference does good monitoring and evaluation make to World Bank project performance in the USA. In his study he revealed common markers of good quality monitoring and evaluation, such as: clear institutional setup and division of labor around monitoring and evaluation activities; simple monitoring and evaluation framework that is well aligned with clients' existing monitoring and evaluation systems; good integration with operational tasks; and a system that can generate regular and timely reporting, and that is used during and after lending. 


\section{METHODOLOGY}

This study deploys descriptive research design, this is because it look for the ascertain factors connected with occasions, outcomes, conditions or types of behavior. It illustrates the presented situation, relationships regarding a problem [13]. The targeted population of the study is 350 employees in TAA located in Ilala Municipality that included Executive officer, Programme Managers, Project Managers, Internal Monitoring officers, M \& E systems experts and Heads of Departments and Units as unit of analysis. The study used solvents formula to calculate a population of selected the sample size of the population was 187 respondents as researched in 2019/20.In order to collect the data required in this study, the researcher used questionnaire for collecting primary data [14] and documentary review for secondary data. The questionnaire was closed ended and was developed following the research objectives and literature review. The questions were informed of English language that's clear to respondents.

\section{RESEARCH FINDINGS}

\section{A. General Characteristics of Respondents}

This section shows respondents' distribution by gender, age, education and work experience. They were analyzed and according to Churchill \& Iacobucci [15] the demographic features may have different responses or opinions on the monitoring and evaluation on the performance of Tanzania Airport Authority.

TABLE 1: GENERAL CHARACTERISTICS OF THE RESPONDENTS

\begin{tabular}{|c|c|c|c|c|}
\hline & & $\begin{array}{l}\text { Frequency } \\
\text { (f) }\end{array}$ & $\begin{array}{c}\text { Percent } \\
(\%)\end{array}$ & $\begin{array}{c}\text { Cumulative } \\
\text { Percent }\end{array}$ \\
\hline \multirow[t]{2}{*}{ Gender } & Male & 74 & 39.6 & 39.6 \\
\hline & Female & 113 & 60.4 & 100.0 \\
\hline \multirow[t]{6}{*}{ Age } & $20-25$ years & 23 & 12.3 & 12.3 \\
\hline & 26-30years & 35 & 18.7 & 31.0 \\
\hline & 31-35years & 30 & 16.0 & 47.1 \\
\hline & 36-40years & 41 & 21.9 & 69.0 \\
\hline & 41-45years & 28 & 15.0 & 84.0 \\
\hline & 46years > & 30 & 16.0 & 100.0 \\
\hline \multirow[t]{4}{*}{ Education } & Certificate & 43 & 23.0 & 23.0 \\
\hline & Diploma & 52 & 27.8 & 50.8 \\
\hline & Bachelor & 70 & 37.4 & 88.2 \\
\hline & Postgraduate & 22 & 11.8 & 100.0 \\
\hline \multirow[t]{5}{*}{ Experience } & $0-5 y e a r s$ & 32 & 17.1 & 17.1 \\
\hline & 6-10years & 49 & 26.2 & 43.3 \\
\hline & 11-15years & 46 & 24.6 & 67.9 \\
\hline & 16-20years & 51 & 27.3 & 95.2 \\
\hline & 21years > & 9 & 4.8 & 100.0 \\
\hline \multirow[t]{7}{*}{ Departments } & Executive officer & 23 & 12.3 & 12.3 \\
\hline & Program managers & 39 & 20.9 & 33.2 \\
\hline & Project managers & 23 & 12.3 & 45.5 \\
\hline & $\begin{array}{l}\text { Internal } \\
\text { monitoring } \\
\text { officers }\end{array}$ & 53 & 28.3 & 73.8 \\
\hline & $\begin{array}{l}\text { M\&E systems } \\
\text { experts }\end{array}$ & 31 & 16.6 & 90.4 \\
\hline & $\begin{array}{l}\text { Head of } \\
\text { departments }\end{array}$ & 18 & 9.6 & 100.0 \\
\hline & Total & 187 & 100.0 & \\
\hline
\end{tabular}

Source: Research (2019).
Table 1 above shows general characteristics of the respondents, in the gender of the respondents in Tanzania Airport Authority, 113 (60.4\%) are female and 74(39.6\%) are male of the total respondents, in this findings indicates that female respond more to the topic concerning with monitoring and evaluation system within the organization.

In the part of Age as shown in Table 1 above 41(21.9\%) have age between $36-40$ years ,35(18.7\%) have age between 26-30years, 30(16.0\%) have age between 31-35 years, $28(15.0 \%)$ have age between $41-45$ years and $23(12.3 \%$ ) have age between 20-25 years that represents of the total respondents.

In the part of education background of the respondents as shown in Table 1 above, 70(37.4\%) having bachelor, 52(27.8\%) having diploma, $43(23.0 \%)$ having certificate and $22(11.8 \%)$ have postgraduate level of education of the total respondents.

In the part of working experience of employees in Tanzania Airport Authority as shown in Table 1 above, 51(27.3\%) are employees who have in experience between 16-20 years, $49(26.2 \%)$ have experience of age 6-10 years , 46(24.6\%) have experience between 11-15years and 9(4.8\%) having experience between 21 years and above of the total respondents. This finding indicates that employees who have experience between 21years and above respond more to the topic monitoring and evaluation.

In the part of working destination of employees in Tanzania Airport Authority, 53(28.3\%) are internal monitoring officer, $39(20.9 \%)$ are Programme Managers, 31(16.6\%,) are M \& E systems experts, 23(12.3\%) are Project Managers, 23(12.3\%) are Executive officer and 18(9.6\%) are Heads of Departments and Units of the total respondents. This finding indicates that employees in $\mathrm{M}$ \& $\mathrm{E}$ systems experts department implement more monitoring and evaluation as shown in the Table 1 above.

B. Determination of the effects of Monitoring and Evaluation Systems on the Organization Performance of the Tanzania Airports Authority Was Identified against Respondents

A five point Likert scale was provided ranging from 1 to 5.00 as shown in the Table 2 below.

TABLE 2: LIKERT SCALING

\begin{tabular}{cccc}
\hline Description & Likert scale & $\begin{array}{c}\text { Mean } \\
\text { Range }\end{array}$ & Interpretation \\
\hline Strongly agree & 1 & $1.00-1.80$ & Very High \\
Disagree & 2 & $1.81-2.60$ & High \\
Neutral & 3 & $2.61-3.40$ & Moderate \\
Agree & 4 & $3.41-4.20$ & Low \\
$\begin{array}{c}\text { Strongly } \\
\text { disagree }\end{array}$ & 5 & $4.21-5.00$ & Very Low \\
\hline Source: Author $(2020)$ & & &
\end{tabular}

Source: Author (2020). 
C. The Role of Monitoring and Evaluation Systems Leads to Organizational Performance

The study tries to analyze the role of Monitoring and evaluation systems leads to Organizational performance. Table 3 shows the summary.

TABLE 3: THE ROLE OF MONITORING AND EVALUATION SYSTEMS LEADS TO ORGANIZATIONAL PERFORMANCE

\begin{tabular}{|c|c|c|c|}
\hline Variable & $\begin{array}{c}\text { Statistics } \\
\mathrm{N}\end{array}$ & Mean & $\begin{array}{c}\text { Std } \\
\text { Deviations }\end{array}$ \\
\hline $\begin{array}{l}\text { Monitoring and evaluation } \\
\text { leads to organization } \\
\text { identifying potential success. }\end{array}$ & 187 & 2.3690 & 1.47295 \\
\hline $\begin{array}{l}\text { Monitoring and evaluating } \\
\text { leads to organization to obtain } \\
\text { information within the time. }\end{array}$ & 187 & 2.4064 & 1.45748 \\
\hline $\begin{array}{l}\text { Monitoring and evaluation } \\
\text { leads to organization reaching } \\
\text { its objectives. }\end{array}$ & 187 & 2.1925 & 1.35414 \\
\hline $\begin{array}{l}\text { Monitoring and evaluation } \\
\text { leads to organization obtaining } \\
\text { feedback of their business }\end{array}$ & 187 & 2.2995 & 1.39359 \\
\hline $\begin{array}{l}\text { Monitoring and evaluation } \\
\text { helps organization during } \\
\text { decision making. }\end{array}$ & 187 & 2.2727 & 1.38170 \\
\hline Averages & 187 & 2.3080 & 1.4120 \\
\hline
\end{tabular}

Source: Author, (2020)

Table 3 above shows that the role of Monitoring and evaluation systems leads to Organizational performance. Monitoring and evaluation leads to organization reaching its objectives, majority of the respondents agreed with high mean of 2.1925 and standard deviation of 1.35414 respectively, this is because when an organization monitor their projects they can be able to evaluate value of their project so that they can be able to know how to control the funds utilized in their projects these findings are the same with ones obtained by Görgens and Kusek [9] in USA which revealed that Evaluation is used in governments to increase transparency, strengthen accountability, and improve performance, whereas performance management systems establish outcome oriented goals and performance targets, they also monitor progress, stimulate performance improvements, and communicate results to higher policy levels and the public.

Monitoring and evaluation helps organization during decision making, majority of the respondents agreed with high mean of 2.2727 and standard deviation of 1.38170 respectively, this indicates that when an organization monitor to their projects they can be able to evaluate fund consumed on that project and able to decide if the projects run in profits or loss, if its operates in profit they can continue with the project and if its making the loss they can be able to determine where the loss came from within the projects these findings are same with findings obtained by Naidoo [3] in South Africa where it was revealed that monitoring and evaluation within the organization helps to provide good governance by increasing transparency, and helped to deepen democracy as it has produced the information for engagement on performance of the State.

Monitoring and evaluation leads to organization obtaining feedback of their business, majority of the respondents agreed with high mean of 2.2995 and 1.39359 standard deviation respectively, this indicates that monitoring and evaluation is important in obtaining feedback for business operations because it enables the owner of the business to identify success or failure of their business operations. Monitoring and evaluation leads to organization identifying potential success, majority of the respondents agreed with high mean of 2.3690 and standard deviation of 1.47295 respectively, this indicates that when organization conducting Monitoring and evaluation to their projects it helps the organization to know if the business operation runs in benefits or losses and helps to identify business network so as to increase its customers hence obtaining profits. Monitoring and evaluating leads to organization to obtain information within the time. Majority of the respondents agreed with mean of 2.4064 and standard deviation of 1.45748 , this indicates that organization can be able to obtain information of their project through monitoring and evaluation. In general these findings indicate that monitoring and evaluation system was important to organizational performance in terms of financial and none financial performance due to majority of the respondents agreed with high mean of 2.3080 and standard deviations of 1.4120 and this findings are similar to the findings obtained by Görgens \& Kusek [9] in United States of America they revealed that Monitoring and Evaluation is a powerful public management tool that can be used to improve the way governments and organizations achieve results and sustaining an M\&E system that can produce trustworthy, timely, and relevant information on the performance of government, civil society, or private sector projects, programs, and policies requires that one overcome many $\mathrm{M} \& \mathrm{E}$ system challenges and approach the implementation of such a system with experience, skill, and real institutional capacity systems.

\section{To Examine How Resource Monitoring and Evaluation Affect Organization Performance}

The study tries to analyze resource monitoring and evaluation affect organization performance. Table 4 shows the summary.

TABLE 4: RESOURCE MONITORING AND EVALUATION AFFECT ORGANIZATION PERFORMANCE

\begin{tabular}{lccc}
\hline \multicolumn{1}{c}{ Variables } & $\begin{array}{c}\text { Statistics } \\
\text { N }\end{array}$ & Mean & $\begin{array}{c}\text { Std } \\
\text { Deviations }\end{array}$ \\
\hline $\begin{array}{l}\text { Monitoring and evaluation helps } \\
\text { organization to retain employees }\end{array}$ & 187 & 2.1070 & 1.27815 \\
$\begin{array}{l}\text { Monitoring and evaluation helps } \\
\text { organization to provide } \\
\text { corporate social responsibility to } \\
\text { the citizens }\end{array}$ & 187 & 2.2727 & 1.38170 \\
$\begin{array}{l}\text { Monitoring and evaluation helps } \\
\text { organization to increase assets. }\end{array}$ & 187 & 2.4171 & 1.46549 \\
$\begin{array}{l}\text { Monitoring and evaluation helps } \\
\text { organization to recruit new } \\
\text { employees }\end{array}$ & 187 & 2.5000 & 1.52546 \\
$\begin{array}{l}\text { Monitoring and evaluation helps } \\
\text { organization to compete with } \\
\text { other organization in market. }\end{array}$ & 187 & 2.4545 & 1.48172 \\
$\quad$ Average & $\mathbf{1 8 7}$ & $\mathbf{2 . 3 5 0 3}$ & $\mathbf{1 . 4 2 6 5}$ \\
\hline
\end{tabular}

Source: Author, (2020) 
Table 4 above shows that resource monitoring and evaluation affect organization performance, Monitoring and evaluation helps organization to retain employees, majority of the respondents agreed with high mean of 2.1070 and standard deviation of 1.27815 respectively, this indicates that when organization conduct evaluation of their project, when that project perform well, the organization gives bonus to its employees. Monitoring and evaluation helps organization to provide corporate social responsibility to the citizens, majority of the respondents agreed with high mean of 2.2727 and standard deviation of 1.38170 respectively, this indicates that when an organization monitor and evaluate her project conducted within the community for the purpose of secure that project within the community and make people surrounding that project to see they own the project, the organization provide social responsibility like construction of hospital within the community. Monitoring and evaluation helps organization to increase assets, majority of the respondents agreed with high mean of 2.4171 and standard deviation of 1.46549 respectively, this indicates that when an organization monitor and evaluate their project its conducted can be able to understand profits obtained within the project hence can increase assets like land, employees etc that can helps organization functioning to enhance organization performance within the public. Monitoring and evaluation helps organization to compete with other organization in market, majority of the respondents agreed with high mean of 2.4545 and standard deviation of 1.48172 respectively, this indicates that when an organization evaluate their conducted project can be able to identify potential success and can be able to compete with other organization who work in the same field of the business. Monitoring and evaluation helps organization to recruit new employees, majority of the respondents agreed with high mean of 2.5000 and standard deviation of 1.52546. This indicates that monitoring and evaluation within the organization projects helps an organization during decision making and enable the organization to recruit more employees within the organization department so that can work together in completion with other organization within the market. In general these findings indicates that resource monitoring and evaluation affect organization performance in terms of reduced employees turn over, potential success identification, to increase assets and increase of production assets due to majority of employees agreed with high men of 2.3503 and standard deviation of 1.4265 and this findings are similar to the findings obtained by Tukwayo [10] in Malawi they revealed that $\mathrm{n}$ monitoring and evaluation within organization helps clarifying scope, purpose, intended use, audience and budget for their conducted project.

\section{E. Inferential Statistics}

This section covers inferential statistics that led to make inferences based on the data collected from the population. They helped to examine the relationship between monitoring and Evaluation (Role of Monitoring and Evaluation systems, Resource monitoring and evaluation) on organizational performance. Correlation statistics were employed in order to determine such relationship.

\section{F. Analysis Model}

Table 5 shows multiple coefficients of variation (R) was 0.917 which entails that the degree of association between organization performance and monitoring and Evaluation systems are positive related. The R Square $\left(\mathrm{R}^{2}\right)$ was 91.7 which imply that $91.7 \%$ variations in organization performance are explained by monitoring and Evaluation systems in the model. While $8.3 \%$ of variations organization performance is explained by random error or other factors.

TABLE 5: ANALYSIS MODEL SUMMARY

\begin{tabular}{ccccccccc}
\hline \multirow{2}{*}{$\begin{array}{c}\mathrm{R} \\
\text { Square }\end{array}$} & \multirow{2}{*}{$\begin{array}{c}\text { Adjusted } \\
\text { R Square }\end{array}$} & $\begin{array}{c}\text { Std. Error of the } \\
\text { Estimate }\end{array}$ & \multicolumn{5}{c}{ Change Statistics } \\
\cline { 5 - 8 } & & & R Square Change & F Change & df1 & df2 & $\begin{array}{c}\text { Sig. F } \\
\text { Change }\end{array}$ \\
\hline .917 & .915 & .39329 & .917 & 669.964 & 3 & 183 & .000 \\
\hline
\end{tabular}

a. Predictors: (Constant), b. Predictors X1, X2 and X3.

Source: Author, (2019).

\section{G. ANOVA}

\begin{tabular}{ccccccc}
\multicolumn{7}{c}{ TABLE 6: ANALYSES OF VARIATIONS } \\
\hline & Sum of Squares & df & $\begin{array}{c}\text { Mean } \\
\text { Square }\end{array}$ & F & \multirow{2}{*}{ Sig. } \\
\hline \multirow{2}{*}{1} & Regression & 112.768 & 3 & 37.589 & 30.428 & $.000^{\mathrm{b}}$ \\
& Residual & 108.710 & 88 & 1.235 & & \\
& Total & 221.478 & 91 & & & \\
\hline
\end{tabular}

a. Dependent Variable: Organization performance, b Predictors: (Constant), $\mathrm{X} 1, \mathrm{X} 2$ and $\mathrm{X} 3$.

Source: Author, (2019).

Table 6 above shows the statistical analysis of variance was done to determine association of variables. It indicates that Monitoring and Evaluation systems were significant effects on organization performance since the p-value were 0.000 , which is less than 5 percent significance level. It implies that the Monitoring and Evaluation systems have a significant influence on enhancing organization performance.

\section{H. Coefficient of Regression}

Coefficient of regression analysis was used to determine relationship between monitoring and evaluation (Role of Monitoring and Evaluation systems, Resource monitoring and evaluation) on organizational performance in Tanzania as shown in Table 7. 


\begin{tabular}{|c|c|c|c|c|c|c|}
\hline \multirow[t]{2}{*}{ Model } & \multirow[t]{2}{*}{ Variable } & \multicolumn{2}{|c|}{$\begin{array}{l}\text { Unstandardized } \\
\text { Coefficients }\end{array}$} & \multirow{2}{*}{$\begin{array}{c}\text { Standardized } \\
\text { Coefficients } \\
\text { Beta }\end{array}$} & \multirow[t]{2}{*}{$\mathrm{t}$} & \multirow[t]{2}{*}{ Sig } \\
\hline & & $\mathrm{B}$ & Std. Error & & & \\
\hline (Constant) & & .248 & .359 & & .691 & .015 \\
\hline $\begin{array}{l}\text { Role of Monitoring and } \\
\text { Evaluation systems }\end{array}$ & $\mathrm{X} 1$ & .545 & .123 & .596 & .518 & .000 \\
\hline $\begin{array}{l}\text { Resource monitoring and } \\
\text { evaluation }\end{array}$ & $\mathrm{X} 2$ & .064 & .131 & .054 & .655 & .000 \\
\hline
\end{tabular}

a. Dependent Variable: Organization performance, b Predictors: (Constant), X1, X2

Source: Author, (2019)

From Table 7 above that shows Coefficients of regression we obtain the model below

$$
\mathrm{Y}=0.248+0.545 \mathrm{X} 1+0.064 \mathrm{X} 2+0.05
$$

$$
\mathrm{Y}=0.907
$$

where $\mathrm{Y}$ is organization performance, $\mathrm{X} 1$ Roles of Monitoring and Evaluation system, $\mathrm{X} 2$ is resource monitoring and evaluation system, taking all variables in monitoring and Evaluation at zero, organization performance in Tanzania is 0.907. According to the model, all the variables are significant, and their significance value was less than 0.05 ; monitoring and Evaluation system is positively correlated with organization performance in Tanzania.

\section{SUMMARY, CONCLUSION AND RECOMMENDATIONS}

\section{A. Introduction}

This part presents the summary of the research findings, conclusion and recommendations derived from the results obtained in this study.

The study aims to assess the effects of monitoring and Evaluation systems on organization performance in Tanzania.

The study established that Organization has employed monitoring and evaluation components having highly employed roles of Monitoring and Evaluation system, resource monitoring. On involvement of monitoring and evaluation system with organization performance, the study recognized that both private and public sector organization in Tanzania must implement monitoring and Evaluation function on organization performance for the purpose of minimizing fraud, public fund misappropriation, risks management and improving transparent and integrity within the organization internal politics, lack of commitment, bureaucracy in management, conflicting values and cultures in the institution, centralization of authority and decision-making, insufficient funds, insufficient remuneration and the effect of globalization for the purpose of emphasizing Organization(Both private and public organization) to reach its goals.

\section{B. Conclusions}

Based on the research findings obtained, the study come with the following conclusions:

The study agreed that majority of the organizations (both public and private sector organization) in Tanzania have highly engaged in Monitoring and Evaluation in their project conducted within the organization, monitoring and Evaluation within the organization have positively relationship with organization performance. Based on the findings, it was concluded that monitoring and Evaluation systems functions improves organization performance in Tanzania, therefore any organization in Tanzania should employ in constant improvement in monitoring and Evaluation system in order to reach organization objectives.

\section{Recommendations}

These are researcher's recommendation based on the findings obtained on the study of monitoring and Evaluation systems, public and private sector organization can use.

Both public and private organization should continue and sustain improve monitoring and Evaluation systems an independent, objective assurance and sound out activity designed to add value and improve an organization's function. It helps an organization in archiving its objectives by bringing an efficient, disciplined approach to evaluate and extend the usefulness of risk management, control, and authority processes to the organization.

\section{Area for Further Study}

This research considered few effects of few parameters of monitoring and evaluation on organization performance in Tanzania. A lot of other factors outside monitoring and evaluation could influence on performance of organization. This provides for a vast area on which father studies can be conducted such as effects of training and development on organization performance.

\section{ACKNOWLEDGMENTS}

I give glory to the Almighty God for his privilege and gift of life as well as for protection to this destination I reached for writing this dissertation. Also, I take this opportunity to convey my sincere thanks to my supervisor, Dr. Juliana Isanzu for her time in providing guidance, encouragement, motivation and vast productive corrections until submission of this dissertation.

My thanks should also go to Tanzania Airport Authority and those who responded to questionnaires, out of which this study was fruitful.

Furthermore, I extend my gratitude to the Director of Directorate of Postgraduate Studies and Research, Kampala International University in Tanzania Prof. AkimMturi; Dean of Faculty of Computing, Management and Social Sciences, 
Dr. Rashid Kiliza; Head of Department of Business and Management, and Social Science and other academic members of staff for their guidance and advocacy during my stay at the University.

Also, I take this opportunity to thank my beloved wife Rehema Mwamwezi including my children, Gloria Godfrey, Godwin Godfrey and Lucy Godfrey. I understood that in my absence you felt solitude, but I appreciate your heart and blessings you threw towards my studies. Your patience, advice, prayers and financial support were tools for my prosperity.

\section{REFERENCE}

[1] Menone, S., Karl, J., \&Wignaraja, K. (2009). Handbook on planning, monitoring and evaluating for development results. New York: UNDP Evaluation Office.

[2] Newcomer, K. E., Hatry, H. P., \& Wholey, J. S. (2010). Planning and designing useful evaluations. Handbook of practical program evaluation, 19(5).

[3] Naidoo, I. A. (2011). The role of monitoring and evaluation in promoting good governance in South Africa: A case study of the Department of Social Development. Johannesburg: University of Witwatersrand

[4] Fu, C. Y., Xie, X., Huang, J. J., Zhang, T., Wu, Q. Y., Chen, J. N., \& Hu, H. Y. (2010).Monitoring and evaluation of removal of pathogens at municipal wastewater treatment plants. Water Science and Technology, 61(6), 1589-1599.

[5] Mackay, K. (2008). Helping countries build government monitoring and evaluation systems: World Bank Contribution to Evidence-based Policy Making. The role of monitoring and evaluation in Evidence-based policy making. Geneva: UNICEF.

[6] Mertens, D. M. (2014). Research and evaluation in education and psychology: Integrating diversity with quantitative, qualitative, and mixed methods. Los Angeles: SAGE Publications, Inc.

[7] Mleke, M. N., \& Dida, M. A. (2020). A Survey of Monitoring and Evaluation Systems for Government Projects in Tanzania: A Case of Health Projects.

[8] Guzmán, M., Irarrázaval, I., \& De los Rios, B. (2014). Monitoring and evaluation system: The case of Chile 1990-2014. Washington, DC: World Bank Group.

[9] Görgens, M., \&Kusek, J. Z. (2010). Making monitoring and evaluation systems work: A capacity development tool kit. Washington, DC: The World Bank.

[10] Tukwayo, P. C. (2018). Evaluation of the effectiveness of the implementation of the staff performance management system in the Department of Social Development: a case study of Eerste River Office (Doctoral Dissertation, Unpublished). Stellenbosch: Stellenbosch University.

[11] Govender, I. G. (2013). Monitoring and evaluation systems for enhancing governance and government legitimacy in South Africa. Journal of Public Administration, 48(1): 811-823.

[12] Raimondo, E. (2016). What difference does good monitoring \& evaluation make to World Bank project performance? Washington, D.C.: World Bank Group.

[13] Khalid, K., Abdullah, H. H., \& Kumar M, D. (2012). Get along with quantitative research process. International Journal of Research in Management, 2(2): 15-29.

[14] Wario, W., \&Khalfan.M. (2015). Principles, Methods and Practices of Social Science Research. Zanzibar: Sumait University Press, Zanzibar.

[15] Churchill, D. A., \& Iacobucci, D. (2010). Market research. Methodological Foundations, 2.

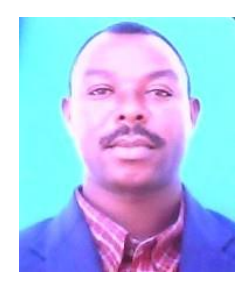

Mr Masawe is born in Kilimanjaro Region at Moshi Rural area on 08 December 1971.

He has completed primary and secondary education. From 1981 to 1987 primary education, from 1988 to 1994 O-level and A- Level secondary education. In 1997 to 1999 Diploma in Aircraft Maintenance Engineering in Military Aviation College at Kizuka Morogoro, in 2011 to 2014 Bachelors of Art in International Business at the University of Greenwich in United Kingdom, and from 2017 up to date Masters in Project Planning and Management where he is still going on with report analysis at Kampala International University Uganda. 